\title{
ResearchOnline@JCU
}

This is the Accepted Version of a paper published in the journal: International Journal of Osteoarcheology

Domett, K.M., Newton, J., O'Reilly, D.J.W., Tayles, N., Shewan, L., and Beavan, N. (2013) Cultural modification of the dentition in prehistoric Cambodia. International Journal of Osteoarcheology, 23 (3). pp. 274-286. 


\section{Cultural Modification of the Dentition in Prehistoric Cambodia}

\begin{tabular}{|r|l|}
\hline Journal: & International Journal of Osteoarchaeology \\
\hline Manuscript ID: & OA-10-0104.R1 \\
\hline Watey - Manuscript type: & Research Article \\
\hline Author: & 14-Dec-2010 \\
\hline Complete List of Authors: & $\begin{array}{l}\text { Domett, Kate; James Cook University, School of Medicine and } \\
\text { Dentistry } \\
\text { Newton, Jennifer; James Cook University, School of Medicine and } \\
\text { Dentistry } \\
\text { O'Reilly, Dougald; Australian National University } \\
\text { Tayles, Nancy; University of Otago, Department of Anatomy and } \\
\text { Structural Bology } \\
\text { Shewan, Louise; University of Sydney } \\
\text { Beavan, Nancy; University of Otago }\end{array}$ \\
\hline Keywords: & \begin{tabular}{l} 
dental ablation, tooth filing, Southeast Asia, Angkor, Iron Age \\
\hline
\end{tabular} \\
\hline & SCHOLARONE \\
\hline
\end{tabular}




\section{Cultural Modification of the Dentition in Prehistoric Cambodia.}

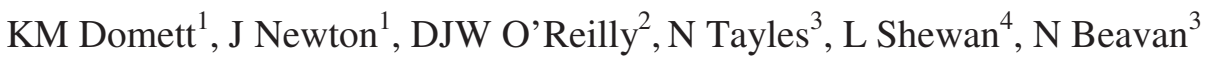

1. James Cook University, Townsville, Queensland, Australia

2. Australian National University, Canberra, ACT, Australia

3. University of Otago, Dunedin, New Zealand

4. University of Sydney, Sydney, New South Wales, Australia

Short title: Dental Modification in Prehistoric Cambodia

Keywords: Dental blation, tooth filing, Southeast Asia, Iron Age, Angkor

Primary author contact details: Dr Kate Domett, School of Medicine and Dentistry, James Cook University, Townsville, QLD 4811, Australia

$\mathrm{Ph}+61747815608 \quad$ Fax +61747815945

E-mail: kate.domett@jcu.edu.au

\section{Grant Sponsorship:}

Australian Research Council Discovery Grant (DP0984968); James Cook University, Australia; Royal Society of New Zealand; Otago Research Grant, Otago University, New Zealand. 


\begin{abstract}
Intentional dental modification, in the form of ablation and filing, is reported for the first time from Cambodia in two late prehistoric sites (Phum Snay and Phum Sophy, c. 2500 to $1500 \mathrm{yrs} \mathrm{BP}$ ). Bioarchaeological research is relatively new for this region and this study significantly adds to our reconstruction of past behaviours in mainland Southeast Asia. The skeletal samples combine both excavated material and large looted collections in the form of ossuaries. People from Phum Sophy and Phum Snay had similar rates of anterior maxillary dental ablation, $60 \%$ and $47 \%$ respectively, and $21.4 \%$ and $7.7 \%$, respectively, in the mandible. Patterns of ablation most commonly involve the removal of the maxillary lateral incisors. Intentional filing was less common than ablation but affected Phum Snay and Phum Sophy individuals to a similar level (4-7\%). Filing was also restricted to the anterior dentition and a range of patterns were evident, many involving filing of the mesial and distal aspect of the crown of the upper and lower incisors and canines to give a pointed appearance. Patterns of ablation or filing were not strongly associated with a particular sex or age group. However, a limited number of ablation and filing patterns were exclusive to each site. The significance of this practice in relation to rites of passage, status, community and family relationships, and trauma is discussed. It is also shown that the modifications show distinct differences in prevalence and pattern, particularly that of filing, to nearby temporal neighbours in southern Cambodia and northeast Thailand suggesting a unique cultural behaviour for this region.
\end{abstract}


Dental modification is common in cultures around the world, both in prehistory and in more recent times (for example Han \& Nakahashi, 1996; Inoue et al., 1995). These modifications reflect a broad range of varied cultural practices (Milner \& Larsen, 1991). Here, for the first time, evidence of two types of dental modification, intentional ablation and filing (intentional abrasion), are reported from prehistoric sites (c. 2500 to $1500 \mathrm{BP}$ ) in northwestern Cambodia. Archaeological research in Cambodia has expanded over the last decade and archaeological work on prehistoric period sites is becoming more common (Reinecke et al., 2009; Stark, 2004). The Angkorian period (1200 to 800 BP) has been studied in depth (for example Clark, 2007; Coedés, 1937-66; Jacques \& Freeman, 1997) but there is now a move towards building a picture of life prior to Angkor (Domett \& O'Reilly, 2009; Domett et al., in press; O'Reilly et al., 2006; Pottier et al., 2007).

This research reports the practice of dental modification in Iron Age Cambodia and discusses the cultural significance of these practices, given the backdrop of potentially unsettled times (Domett et al., in press). Was tooth modification meant to beautify the recipient or perhaps create a menacing visage or was it a more complex ritual associated with tribal affiliation or rites of passage?

Dental modification in prehistoric mainland Southeast Asia has been recorded for a small number of skeletal samples, ranging from Neolithic to Iron Age, from Thailand to Vietnam (Nelsen et al., 2001; Nguyen, 2009; Oxenham et al., 2002; Sangvichien et al., 1969; Tayles, 1996) and in some ethnographic studies (Franks 1926 cited in Scott \& Turner, 1997; Zumbroich, 2009). Dental modifications from mainland Southeast Asia are predominantly intentional ablation (Tayles, 1996) or tooth blackening (Tayanin \& Bratthall, 2006; Zumbroich, 2009). Observations of dental abrasion in the form of intentional filing, in this region are, until now, non-existent in the archaeological record.

\section{MATERIALS}

The skeletal samples are from the sites of Phum Snay and Phum Sophy, both small, modern, mounded villages in northwest Cambodia (Figure 1). The samples both consist of a small archaeologically excavated skeletal sample with additional, stratigraphically unprovenanced, ossuary material. Both ossuaries contain prehistoric material retrieved after 
extensive looting by the current inhabitants of areas immediately within the villages of the excavated sites.

Phum Snay was excavated in 2001 and 2003 by O'Reilly in collaboration with the Cambodian Royal University of Fine Arts (RUFA), the University of Otago (New Zealand) and James Cook University (Australia). Excavations uncovered a total of 23 graves, of which 21 contained human bone (Domett \& O'Reilly, 2009). The ossuary collection (MNI = 134) is currently stored in wats (temples) at Phum Snay and Siem Reap. The ossuary sample is strongly believed to come from Phum Snay and, despite the lack of stratigraphic provenance, it was likely to be from a similar time period as the prehistoric cemetery excavated, which appears to have had a brief span of use starting just prior to the $1^{\text {st }}$ millennium and up to the $2^{\text {nd }}$ century $\operatorname{AD}(c .2350$ to 1800 yrs BP) (O'Reilly et al., 2006).

Phum Sophy was excavated in 2009 by O'Reilly in collaboration with the University of Sydney, Ministry of Culture and Fine Arts of Cambodia, James Cook University and the Australian National University. A total of six burials were found, however, this skeletal collection was augmented by a large ossuary at the village wat. These human bones were collected and stored at the wat by villagers after the site was extensively looted. The MNI analysed to date is 37 . Dating from the site has not yet been fully completed but the first dataset of radiocarbon dates from the ossuary material date to between the $1^{\text {st }}$ century AD to as late as the $7^{\text {th }}$ century AD (1395 to $1890 \mathrm{yrs}$ BP) (N. Beavan, pers.comm). Thus, the two sites are at least partially contemporaneous.

\section{METHODS}

The estimation of age-at-death was completed using standard morphological methods, prioritising, depending on completeness, late fusing epiphyses, pubic symphysis morphology and dental wear in adults following Buikstra and Ubelaker (1994). Given the isolated nature of most of the collection, most crania and mandibles were aged using only dental wear seriation. Adults were then classified into relative age groups of young, middle and old age or unknown age adult; further accuracy of aging was not possible for adults. Subadults were aged prioritising dental eruption and calcification followed by diaphyseal lengths (Buikstra \& Ubelaker, 1994). 
Sex determination relied predominantly on pelvic and skull morphology following Buikstra and Ubelaker (1994) standards. Sex determination of the isolated crania are provided where completeness allowed but estimations were generally not attempted for isolated maxillae and mandibles.

The condition of all teeth was recorded in detail, with differentiation of antemortem and postmortem loss of teeth based on evidence of alveolar remodelling. The absence of a tooth may be caused by a variety of factors, including congenital failure to develop (agenesis), failure to erupt, pathological or accidental loss, or intentional removal (ablation). Differentiating between these causes requires a detailed assessment of the surrounding alveolar bone and teeth. In order for intentional ablation to be considered the most likely 'diagnosis' there should be no evidence for disease in the adjacent teeth or alveolar bone, symmetry or near symmetry of tooth loss should be apparent, and the pattern of loss should be repeated among individuals within the sample (Merbs, 1968). In addition, the amount of space remaining and the presence or absence of interproximal wear facets on remaining adjacent teeth were recorded (Milner \& Larsen, 1991). The presence of the last two characteristics confirms that a tooth had been present, allowing a differentiation between antemortem loss and agenesis. Only maxillae and mandibles with a complete set of anterior teeth (canines, lateral and central incisors) were included in this analysis. Results are presented as proportions of the total number of complete maxillae or mandibles and not presented by individual as the majority of observations were made on isolated maxillae or mandibles.

Dental abrasion was also recorded systematically. Abrasion can be defined as "[w]ear that results from contact with objects other than teeth" (Hillson, 2008: 309). This might be through deliberate modification, using teeth as tools, or through contact with abrasive foodstuffs or other artefacts such as the use of the clay pipe in Europe creating distinctive notches in the canines and premolars (Kvaal \& Derry, 1996). Differentiating between intentional abrasion and that resulting from using teeth as tools requires careful observation of the pattern and location of abrasions, the symmetry of teeth affected and the overall prevalence in a population (Blakely \& Beck, 1984). For example, when used as tools, teeth typically display asymmetrical wear, while intentional modification tends to be symmetrical. In addition, task-related activities are inclined to affect the occlusal or interproximal surfaces of teeth, while intentional abrasion is carried out on crown edges or labial surfaces (Blakely $\&$ Beck, 1984). Results on the abrasion of teeth are presented per maxilla or mandible but 
included some incomplete anterior dentitions if they had obvious signs of intentional abrasion.

\section{RESULTS}

\section{Ablation}

At both Phum Snay and Phum Sophy, high rates of anterior antemortem tooth loss have been identified (Table 1). In the majority of individuals the loss was symmetrical ( $83.5 \%$ in the maxilla and $61.1 \%$ in the mandible; Table 2 ) and there was adequate space between remaining teeth ( $83.5 \%$ of teeth). Observations of interproximal facets on remaining teeth were limited by the level of concretions adhering to the material. The occurrence of associated pathology in adjacent teeth or alveolar bone was low to non-existent. Based on all this evidence, and consistency with Merbs (1968) criteria, it is concluded that the high rate of loss of anterior teeth in these samples was intentional ablation. A small minority of cases may be the result of agenesis, particularly in those few instances where there is no space for the missing teeth although this may also be explained by mesial migration of the remaining teeth post ablation.

Phum Snay and Phum Sophy have similar high rates of ablation in the maxilla, with $60.2 \%$ and $47.8 \%$ of maxillae affected, respectively. Both sites show less ablation in the mandible (21.4\% and $7.7 \%$ respectively). At both sites, males showed more ablation than females in the maxilla, although the differences were not statistically significant (Table 1). In the mandibles, Phum Snay males showed more ablation than females, while the reverse was the case at Phum Sophy, although neither sex difference was statistically significant and samples of mandibles were quite small (Table 1).

All adult age groups were affected by ablation (Table 1). In the Phum Snay sample there is a general increase of ablation with advancing age in both the maxilla and mandible. In the mandibular sample from Phum Sophy, only older adults showed ablation, while the maxilla was affected more in younger and older adults. Overall, with both samples combined, there is a general increase of the prevalence of ablation with advancing age but not to a statistically significant level (Table 1). 
Subadults from both sites were under-represented. However, of the 16 partial anterior dentitions (ranging in age from 7-15 years), none had any sign of ablation. Therefore based on the available evidence, the earliest age of occurrence of ablation would appear to be in young adulthood. A number of the young adults showing ablation were yet to show eruption of the third molars or completion of fusion of some of the late fusing epiphyses, leading to the conclusion that the youngest age of occurrence of ablation was between 18-25 years.

The patterns of ablation in the anterior teeth are detailed in Table 2. The majority of cases in both the maxilla and mandible show symmetrical patterns. In the maxilla, the most common pattern is that involving the loss of both lateral incisors (72.9\%) (Figure 2), with the second most common pattern involving the loss of both lateral incisors and canines $(10.6 \%)$. The involvement of the central incisors was rare $(2 / 85,2.4 \%)$. In the mandible, the most common pattern of loss involved the ablation of all four incisors (55.5\%) (Figure 3). All other patterns only occurred in one individual each. This distribution of patterns was similar at both Phum Snay and Phum Sophy. There appears to be no specific pattern that is common to a particular sex or age group overall. However, only Phum Snay males and Phum Sophy females showed Pattern 9 in the mandible, although sample sizes are small in these cases.

Due to the isolated nature of the majority of maxillae and mandibles, it is not possible to gain a detailed picture of the pattern of tooth loss in an individual. However, to gain an idea of overall patterns in individuals, six excavated individuals from Phum Snay with both complete maxilla and mandible, can be observed. Four individuals (three males, two middle aged and one young adult, and one middle aged adult female) had Pattern 1 in the maxilla, and three of these also had Pattern 9 in the mandible (Figure 4) and one (the female) had Pattern 11. These four individuals were from the 2003 excavation square. Two individuals (one male and one female, both young adults) had Pattern 2 in the maxilla but all mandibular teeth were present; both were from the 2001 excavation square.

The non-symmetrical patterns, Patterns 3 to 8 and 11 to 17 (Table 2) may include some cases where accidental loss occurred during the intentional removal of the teeth. For example, it is possible that the loss of a central incisor in Pattern 7 was accidental, occurring during the removal of an adjacent lateral incisor. It is easy to imagine that if the technique of removing teeth involved knocking them out, rather than pulling them out, a slip to the left or right resulting in the removal of an unintended tooth is possible. The technique of removing teeth by knocking out rather than pulling out is strongly suggested by the observation of a 
number of partially remodeled sockets showing a remaining tooth root (Figure 5). This was evident in five cases from Phum Snay and two from Phum Sophy. Unfortunately radiography was not possible as there are limited radiographic facilities in Siem Reap, Cambodia. Another complicating factor for radiography was the presence of considerable postdepositional soil in the bone.

Filing

Both the Phum Sophy and Phum Snay samples also showed a number of cases of unusual abrasion in the upper and lower anterior dentition. Based on the location of the abrasion (crown edges) and the symmetrical nature of many cases, the abrasion was determined to be the result of intentional filing (Blakely \& Beck, 1984). The prevalence of filing was low in both samples (ranging from $4.3 \%$ to $6.9 \%$ ). In the Phum Sophy sample four maxillae (6.9\%) and four mandibles (4.3\%) were affected, while in the Phum Snay sample, maxillae were affected slightly less $(9 / 187,4.8 \%)$ than in the mandible $(8 / 123,6.5 \%)$. There appears to be no strong correlation with age or sex (Table 4 and 5) in each sample although of the 17 maxillae and mandibles affected in the Phum Snay sample, $41.2 \%$ were in young adults.

At both sites crowns of the anterior maxillary or mandibular dentition were filed either on the mesial or distal aspect at an angle or both aspects were filed to create a pointed tooth (Figure 6, Figure 7 and Figure 8). The different patterns of filing are depicted in Table 3 (maxilla) and Table 4 (mandible). Not all anterior dentitions observed were complete; therefore the allocation to a particular pattern was not possible in all cases as noted in the table. There is an overlap of only two patterns between Phum Snay and Phum Sophy (Pattern $\mathrm{C}$ and possibly H); abrasion Patterns A, B, D, E, G, and I are exclusive to Phum Snay and Pattern F and J are exclusive to Phum Sophy. Another key pattern is that Phum Sophy dentitions always showed the involvement of canines, while only two cases involved the canines in the Phum Snay sample.

\section{DISCUSSION}

\section{Evidence from Southeast Asia}


Ablation has been documented in some parts of prehistoric Asia, but it is certainly not ubiquitous; dental filing is even rarer. In mainland Southeast Asia, missing anterior teeth have been most thoroughly documented in only two samples. A study on the Neolithic Thai site (c. 4000-3500 years BP), Khok Phanom Di (Figure 1), indicates ritual ablation is present in $72 \%$ of the sample (Tayles, 1996). The similarities in the pattern of tooth loss with the Cambodian samples include the most frequent loss being in the maxilla and involving the maxillary lateral incisors (24\% of those with missing teeth at Khok Phanom Di). However a key difference from Cambodian patterns is the more common involvement of the maxillary central incisors at Khok Phanom Di.

The second study was based on a northeastern Iron Age Thai sample, Noen U-Loke (Figure 1) (Nelsen et al., 2001). This skeletal sample showed many individuals with missing upper lateral incisors, many with inadequate space and asymmetrical loss, arguing against an ablation aetiology in the majority of cases. Congenital absence has been reported to be higher in Asian populations, and the high involvement at Noen U-Loke is thought to be a result of homogeneity in the population (Nelsen et al., 2001). The possibility of both agenesis and ablation being present is also broached, albeit cautiously, with the suggestion that those individuals without agenesis attempted to emulate the appearance of those with agenesis (Nelsen et al., 2001).

Further evidence of the antiquity of ablation in Southeast Asia has been noted in Neolithic skulls from the cemetery of Ban Kao in west central Thailand (Figure 1) (Sangvichien et al., 1969). The youngest individual from Ban Kao with ablation (and subsequent remodelling) is 18 years old, suggesting an early adolescent ritual. Much younger children have missing teeth at Khok Phanom Di, some of pre-pubertal age, suggesting an early start to this practice (Tayles, 1996). The sample of Ban Kao also details a number of cases of abrasion, however, this and other studies on prehistoric Thai skeletal material do not show similar patterns of intentional filing to the Cambodian skeletal samples. It is likely that they all represent abrasion from occupationally related activities, given the asymmetrical nature of the abrasion and the inclusion of some posterior teeth (Sangvichien, 1966; Tayles et al., 2007; Wales, 1937; Wales, 1964).

Evidence of dental ablation from prehistoric Cambodia has been noted (but not detailed) in a small number of individuals at a number of sites including two prehistoric sites nearby and broadly contemporaneous with Snay and Sophy: Koh Krabas (Wallwork, 2006) 
and Krasang Thmei (2050 to 1660 yrs BP, N. Beavan, pers.comm., Domett, 2005) (Figure 1). Further east, situated closer to Angkor, the sites of Koh Ta Méas (c. 3000BP) and Prei Khmeng (M.Frelat, pers.comm; Pottier, 2006; Pottier et al., 2007) both show one or two individuals with ablation. Interestingly though, within the more southern regions of Cambodia, no ablation has yet been observed in prehistory. The southern samples from Angkor Borei (Ikehara-Quebral, 2010; Pietrusewsky et al., 2006) and Prohear (Reinecke et al., 2009) (Figure 1), both from similar time periods as Phum Snay and Phum Sophy, have no ablation, although some abrasion may be present in the Angkor Borei sample (IkeharaQuebral, 2010). It is not clear whether the abrasion is intentional or from incidental cultural use, but from one image provided, the anterior mandibular teeth are filed to a point in a similar manner to those in the northwest (Ikehara-Quebral, 2010).

Anterior antemortem tooth loss is recorded in both Neolithic and Metal Period Vietnam. It is suggested to be the result of ablation for the Neolithic Da But samples but more likely to have been caused by using teeth as tools in the later samples (Oxenham et al., 2002). In the Neolithic cemetery at Man Bac (3800 and 3400 BP), anterior dental ablation is suspected in a number of individuals (Nguyen, 2009; Oxenham et al., 2009; Domett unpublished observations).

There is considerable evidence of dental modification, mostly ablation, among Chinese populations, beginning around 6500 years ago (Zhu Feisu $1984 \&$ Mote 1964 cited in Blench, 2008; Han \& Nakahashi, 1996). Han and Nakahashi (1996) propose the spread of ablation through China from the Shandong province to the east from as early as 6500 years ago. It is possible this spread continued into southern China, such as into the Daic people (Blench, 2008) and into Southeast Asia, perhaps reaching as far as southeastern Thailand (such as Khok Phanom Di) and picked up by particular groups along the way. Although, there is a distinctive lack of widespread dental modification in the Bronze Age: none in the sample from Nong Nor (Tayles et al., 1998) and only four tentative cases in mandibles from Ban Lum Khao (Domett, unpublished observations). Nor are there any clear patterns evident from other sites that include Bronze Age such as Ban Chiang, Non Nok Tha (Douglas, 1996) or Ban Non Wat, although analyses of this latter site are not yet complete (Tayles and Domett, unpublished observations). Thus, there appears to be a predominance of dental modification in the Neolithic and Iron Age but not in the intervening Bronze Age. 
There is possible archaeological evidence for contact between Phum Snay and Iron Age communities in Northeast Thailand. O'Reilly et al. (2006) reported the finding of 'Phimai black' pottery at Phum Snay and other characteristics similar to the northeast Thai sites such as Noen U-Loke. This contact continued into the Angkorian period with the establishment of the Prasat Hin Phimai in northeast Thailand, an extension of the Angkorian complex (Figure 1). Given the high proportion of dental agenesis at Noen U-Loke (Nelsen et al., 2001), emulation by Cambodian communities could be a further possibility for the transfer of this practice between communities.

India may too have had an influence on cultural practices within Southeast Asia. In both prehistoric and modern communities there are observations of intentional dental modification (eg. notching and chipping) but no ablation or filing, (Kennedy et al., 1981). Thus there are more similarities between dental modification practices in China and Southeast Asia than between India and Southeast Asia.

\section{Techniques of dental modification}

As discussed above, it is likely that in the Cambodian samples teeth were knocked out rather than pulled out. Ethnographic evidence from around the world indicates that this is a common method. In Hawai'i, a stick was held against the tooth, which was then knocked out by striking the stick with a rock (Pietrusewsky \& Douglas, 1993). This has also been suggested for the Jomon people in Japan (Takenaka et al., 2001). Takenaka et al. (Takenaka et al., 2001: 51)51) indicate another possible method in the Jomon people, that of extraction, "which involves the pulling or prying out of the teeth by use of a piece of a cord or some sort of forceps-like instrument." Extracting the whole tooth, crown and root, would be a particularly difficult and painful task for the longer rooted upper canines and incisors, but there is evidence in some parts of the world, such as Kenya, that this was the technique used (Inoue et al., 1995).

Ethnographic studies detailing the techniques of dental filing differ around the world. Hillson (2008) suggests that mutilation by cutting, drilling or filing teeth occurred over a long time period. This is supported by the lack of associated pathology. Modifications made piecemeal over time allows the formation of secondary dentine, limiting the exposure of the pulp cavity and consequent periapical infection (Hillson, 2008). In Bali, the modern day practice of filing of incisors and canines is performed with a variety of instruments such as a hammer, chisel and file (Hobart et al. 1996 cited in Mower, 1999). In Borneo, Jones (2001) 
describes how the process is initially achieved with a heavy bladed knife called a parang and continued with a stone for finer detailing. A 'medicine man' is responsible for teeth filing in Moi adolescent girls and boys of Vietnam and carries out the procedure with stones with the ultimate intention of chipping the crown tooth away (Franks 1926 cited in Scott \& Turner, 1997). While this is described as 'filing' in the literature, it could ultimately appear as 'ablation' in the skeletal record.

\section{Cultural significance of dental modification in Cambodia}

The intention behind dental modification is difficult to discern from archaeological evidence alone. Theories, mostly based on ethnographic studies, include status, coming-ofage, marriage, mourning, tribe or family association, ornamentation and beautification (Finucane et al., 2008; Han \& Nakahashi, 1996; Pietrusewsky \& Douglas, 1993; Tayles, 1996). The possibilities abound for prehistoric Cambodia. Through an analysis of the patterns of dental modification between males and females, different age groups and different sites, and in conjunction with contextual and ethnographic evidence, it may be possible to make some suggestions regarding the cultural significance of this practice.

Over both samples, males were more likely to have ablation than females, although not to a statistical level of significance. There was a general increase in ablation with age from 18 years onwards within Phum Snay. Phum Sophy individuals showed a different age related pattern, with maxillae more likely to be affected in older individuals, while younger adults were more often affected in the mandible. Evidence from both sites could perhaps suggest there is an age related factor behind this ritual. This may include practicing ablation at significant periods of life such as early adulthood, marriage, or death of a relative. Harunari (1973 cited in Han \& Nakahashi, 1996) suggest premolars were extracted as a sign of mourning in Japan, the upper canines to mark adulthood, and the mandibular teeth as a sign of marriage. The asymmetrical patterns at Phum Snay and Sophy may also represent a stage in the process of ablation that would eventually lead to removal of teeth in a symmetrical pattern. However, the final result had not been attained as death came first. Alternatively, the individual may not have been entitled to the removal of particular teeth until they had met the requirements such as marriage, birth of a child, or death of a particular relative. The patterns of filing in the maxilla also support this idea, with a possible progression pattern of filing (from Pattern A through to $\mathrm{C}$, Table 3) although this is not related to age, it may be related to 
eligibility. The change from Pattern A to B and B to C involve the filing of only one or two additional surfaces, all moving to involve more distal teeth.

Eligibility may also have been dependent on status or position within the community. The status of an individual dictated how many times a person had their teeth modified in the Dyak people of Borneo. For example, the headman may have up to three treatments coinciding with various life events, while a priest-doctor may only have two (Jones, 2001). This group used a combination of teeth filing and blackening, creating a similar appearance to the Cambodian samples, with the additional involvement of central incisors and premolars (Jones, 2001). The severity of the filing varied amongst tribes and in some only women had their teeth filed while men underwent other types of dental modification (Jones, 2001).

The association between dental modification and grave goods as a tenuous proxy measure of status, can only be investigated for six individuals from the Phum Snay excavations; all six had ablation. There were, in general, two patterns of ablation in these individuals (Patterns 1 and 9 together and Pattern 2 only). In regards to status, no link could be made between dental modification pattern and grave goods. There were a number of distinctive grave goods such as a large sunbear canine in two males, ceramic epaulettes in one male and one female, long iron swords in three male graves and iron torques in two female graves (O'Reilly et al., 2006). However, no patterns between these grave goods and their patterns of ablation could be discerned. Such links with grave goods were also not evident at the Thai sites of Khok Phanom Di (Tayles, 1996) or Noen U-Loke (Nelsen et al., 2001). There was one unique individual from Phum Snay who had filing and ablation (PS03 B2). This was one of the two males with a sunbear canine and quite a large range and quantity of grave goods including a long iron sword, other weaponry and many whole pots suggesting high status within the community (O'Reilly et al., 2006).

While there was considerable overlap in patterns of ablation and filing between Phum Snay and Phum Sophy, there were some key differences. All filing cases from Phum Sophy involved canines, while only two individuals from Phum Snay had canines filed. There were also patterns of ablation and filing that were exclusive to each group discussed above. Overall, there was considerably less variation in patterns in the Phum Sophy samples. The limited overlap in patterns could be a reflection of the limited contemporaneity of the sites, with patterns changing over time, rather than relating to specific communities. There may also have been only a small degree of intermarriage from other communities (not necessarily 
solely between Phum Snay and Sophy) with different dental modification practices or patterns. Although no evidence was found in published material, there is a belief that symbolic tooth filing was part of the traditional marriage process in Cambodia until recent times (M.Vickery, pers.comm.) although nothing is yet known of marriage patterns and the movement of people between communities in prehistory. This may be elucidated by strontium isotopic analyses currently underway. However, given the geographic closeness of Phum Snay and Phum Sophy, it is likely that isotopic variation will not be large, but values may show the influx of more distant migrants (and their cultural practices). Marriage patterns and migration in prehistory have been investigated for prehistoric Thailand. New research at Iron Age Noen U-Loke, a temporally and geographically relevant site to those studied here, show remarkably homogenous strontium and carbon isotope ratios suggesting a lack of long range migration in the Iron Age and no obvious marriage patterns (Cox et al., 2010). It is likely intermarriage existed between nearby villages. The nearby Bronze Age site of Ban Lum Khao, in contrast, showed values suggestive of patrilocality with some longer range migration (Bentley et al., 2009). While matrilocality has been suggested for northeast Ban Chiang (spanning early Bronze and Iron Ages) and coastal Neolithic Khok Phanom Di during the intensification of agriculture development (predominantly through the Neolithic and into the Bronze Age, although neither site shows clear-cut evidence for this (Bentley et al., 2005; Bentley et al., 2007).

Dental modification patterns may also be linked with occupation and dietary isotopic studies (carbon and nitrogen) at Phum Snay and Sophy may also be of use. A study of the Jomon (Japan) period individuals with ablation has linked different patterns of ablation with different dietary dependencies (Kusaka et al., 2008; Kusaka et al., in press). Males with one ablation pattern showed a greater component of terrestrial resources in their diet, thus were likely to be hunters; while those with a different ablation pattern, showed an emphasis on marine resources and were more likely to be fishermen (Kusaka et al., 2008; Kusaka et al., in press).

Differences in patterns of ablation and filing between the sites may also reflect an intention to visually link oneself with a particular community or region. This may have been particularly important during this time as other skeletal evidence indicates a significant amount of violence, probably intercommunity violence, was occurring (Domett et al., in press). If communities were fighting each other, a visual link to ones allegiance may have been useful; alternatively or additionally, the appearance of very pointed teeth may have 
created a menacing image. In the lead up to the development of the Angkorian state, it is likely that rulers were beginning to take control over resources and they may have met some resistance in this by rural communities. It is also possible that some teeth were simply lost accidentally and, considering the level of violence in the Phum Snay population (Domett et al., in press), some tooth loss may have been from interpersonal violence. However, the high levels of symmetrical tooth loss and the retention of central incisors argue against trauma as a collective explanation for Phum Snay.

The variation among groups is evident from ethnographic studies around island Southeast Asia. Intentional filing has been practiced in Indonesia, Borneo and the Philippines, frequently alongside tooth blackening. However, patterns vary considerably. In Bali teeth are filed and blackened as part of a rite into adulthood for both men and women, some time between puberty and marriage. However, the six maxillary anterior teeth are filed so that occlusal edges are uniformly in line with each other to reduce their similarity to animal fangs to widen the gap between animals, particularly dogs, and humans, as animals are seen as unhygienic (Forge, 1980; Reed, 1988 cited in Mower, 1999). In contrast, as noted above the Dyak people of Borneo file their teeth to a point as a sign of status.

Evidence for tooth blackening is unlikely to survive in skeletal samples however this is a practice described ethnographically for many mainland and island Southeast Asian peoples such as Vietnamese (Frank 1926 cited in Scott \& Turner, 1997), Thai (Mote 1964 cited in Sangvichien, 1966) and the Filiopino (Zumbroich, 2009). This modification would actually give the appearance of missing teeth; perhaps this was a less brutal, and possibly more recent, way of 'ablating' teeth. According to studies, tooth blackening is performed for a number of reasons: blackened teeth were not only more attractive but are believed to be stronger and healthier and is an important sign of progression into adulthood or marriageability (Tayanin \& Bratthall, 2006; Zumbroich, 2009).

\section{Conclusions}

In Milner and Larsen's (1991) detailed review of dental modification, they emphasise the importance of the analysis of dental modification: "These aspects of the dentition reflect a diverse array of cultural practices, so they are of special significance in the reconstruction and broader understanding of past human behavior" (Milner \& Larsen, 1991: 357). As has been shown in prehistoric Cambodia, dental ablation and filing appears to have been common in the northwestern region. The modifications show distinct differences in prevalence and 
pattern, particularly that of filing, to nearby temporal neighbours in southern Cambodia and northeast Thailand suggesting a unique cultural behaviour for this region.

\section{Acknowledgements}

Thanks to staff and students at the RUFA, Phnom Penh; Ministry of Culture and Fine Arts of Cambodia; to Dr Christophe Pottier at the l'Ecole Française d'Extrême-Orient in Siem Reap for lab space; to Preah Maha Vimaladhamma Pin Sem Sirisuvanno at Wat Rajabo in Siem Reap and Phum Snay and Phum Sophy elders for access to the specimens, and the University of Sydney Robert Christie research centre in Siem Reap. Radiocarbon dating was completed by Dr Stewart Fallon and Dr Richard Armstrong at the Radiocarbon dating Laboratory, Research School of Earth Sciences, The Australian National University (ANU). We would also like to thank George R. Scott and two anonymous reviewers for providing useful comments on earlier drafts. 


\section{REFERENCES}

Bentley RA, Cox K, Tayles N, Higham C, Macpherson C, Nowell GM, Cooper M, and Hayes TEF. 2009. Community diversity at Ban Lum Khao, Thailand: Isotopic evidence from the skeletons. Asian Perspectives 48(1): 79-97.

Bentley RA, Pietrusewsky M, Douglas MT, and Atkinson TC. 2005. Matrilocality during prehistoric transistion to agriculture in Thailand? Antiquity 79: 865-881.

Bentley RA, Tayles N, Higham CFW, Macpherson C, and Atkinson TC. 2007. Shifting gender relations at Khok Phanom Di, Thailand: Isotopic evidence from the skeletons. Current Anthropology 48(2): 301-314.

Blakely RL, and Beck L. 1984. Tooth-tool use versus dental mutilation: a case study from the prehistoric Southeast. Midcontinental journal of archaeology 9(2): 269-277.

Blench R. 2008. The prehistory of the Daic (Tai-Kadai) speaking peoples and the hypothesis of an Austronesian connection. 12th EURASEAA meeting. Leiden.

Buikstra JE, and Ubelaker DH, (eds). 1994. Standards for Data Collection from Human Skeletal Remains. Arkansas Archaeological Survey: Fayetteville, Arkansas. 206 p.

Clark J, (ed). 2007. Bayon: New Perspectives. River Books: Bangkok.

Coedés G. 1937-66. Les Inscriptions du Cambodge. l'École Française d'Extrême Orient: Hanoi and Paris.

Cox KJ, Bentley RA, Tayles N, Buckley H, R., Macpherson C, and Cooper MJ. 2010. Intrinsic or extrinsic population growth in Iron Age northeast Thailand? The evidence from isotopic studies. Journal of Archaeological Science. DOI: 10.1016/j.jas.2010.10.018

Domett KM. 2005. The Skeletal Remains from Krasaing Thmei, Banteay Meanchey Province, Cambodia. Townsville: James Cook University. $22 \mathrm{p}$.

Domett KM, and O'Reilly DJW. 2009. Health in Pre-Angkorian Cambodia: a bioarchaeological analysis of the skeletal remains from Phum Snay. Asian Perspectives 48(1): 56-78.

Domett KM, O'Reilly DJW, and Buckley H, R. in press. Bioarchaeological Evidence of Conflict in Iron Age, Northwest Cambodia. Antiquity.

Douglas MT. 1996. Paleopathology in human skeletal remains from the pre-metal, Bronze and Iron ages, northeastern Thailand [PhD dissertation]. Hawaii: University of Hawaii.

Finucane BC, Manning K, and Touré M. 2008. Prehistoric dental modification in West Africa - early evidence from Karkarichinkat Nord, Mali. International Journal of Osteoarchaeology 18(6): 632-640. DOI: 10.1002/oa.957

Forge A. 1980. Tooth and fang in Bali. Canberra Anthropology 3(1): 1-16. DOI: $10.1080 / 03149098009508613$

Han K, and Nakahashi T. 1996. A comparative study of ritual tooth ablation in ancient China and Japan. Anthropological Science 104(1): 43-64.

Hillson S. 2008. Dental Pathology. In: Biological Anthropology of the Human Skeleton, Katzenberg MA, and Saunders SR, (eds). 2nd ed. Wiley: Hoboken, New Jersey.

Ikehara-Quebral R. 2010. An assessment of health in early historic (200 B.C. to A.D. 200) inhabitants of Vat Komnou, Ankgor Borei, Southern Cambodia: A bioarchaeological perspective. [PhD dissertation]. Hawai'i: University of Hawai'i at Mānoa.

Inoue N, Sakashita R, Inoue M, Kamegai T, Ohashi K, and Katsivo M. 1995. Ritual ablation of front teeth in modern and recent Kenyans. Anthropological Science 103(3): 263277. 
Jacques C, and Freeman M. 1997. Angkor. Cities and Temples. River Books: Bangkok. Jones A. 2001. Dental transfigurements in Borneo. British Dental Journal 191(2): 98-102. Kennedy KAR, Misra VN, and Burrow CB. 1981. Dental Mutilations from Prehistoric India. Current Anthropology 22(3): 285-286.

Kusaka S, Ikarashi T, Hyodo F, Yumoto T, and Katayama K. 2008. Variability in stable isotope ratios in Late-Final Jomon communities in the Tokai coastal region and its relationship with sex and ritual tooth ablation. Anthropological Science 116(2): 171181. DOI: $10.1537 /$ ase. 070703

Kusaka S, Nakano T, Yumoto T, and Nakatsukasa M. in press. Strontium isotope evidence of migration and diet in relation to ritual tooth ablation: a case study from the Inariyama Jomon site, Japan. Journal of Archaeological Science. DOI: 10.1016/j.jas.2010.09.001

Kvaal SI, and Derry TK. 1996. Tell-tale teeth: abrasion from the traditional clay pipe. Endeavour 20(1): 28-30. DOI: 10.1016/0160-9327(96)10006-5

Merbs CF. 1968. Anterior tooth loss in Artic populations. Southwestern Journal of Anthropology 24: 20-32.

Milner GR, and Larsen CS. 1991. Teeth as artifacts of human behavior. In: Advances in Dental Anthropology, Kelley MA, and Larsen CS, (eds). Wiley-Liss: New York. p 357-378.

Mower JP. 1999. Deliberate ante-mortem dental modification and its implications in archaeology, ethnography and anthropology. Papers from the Institute of Archaeology 10: 37-53.

Nelsen K, Tayles N, and Domett K. 2001. Missing lateral incisors in Iron Age Southeast Asians as possible indicators of dental agenesis. Archives of Oral Biology 46: 963971.

Nguyen LC. 2009. Customs and habits of people in prehistorical period of Viet Nam. 19th Indo-Pacific Prehistory Association Congress. Hanoi.

O'Reilly DJW, von den Driesch A, and Voeum V. 2006. Archaeology and archaeozoology of Phum Snay: a late prehistoric cemetery in northwestern Cambodia. Asian Perspectives 45(2): 188-211.

Oxenham MF, Nguyen LC, and Nguyen KT. 2002. Oral health in northern Vietnam: Neolithic through Metal Periods. Indo-Pacific Prehistory Association Bulletin 22: 121-134.

Oxenham MF, Tilley L, Matsumura H, Nguyen LC, Nguyen KT, Nguyen KD, Domett K, and Huffer D. 2009. Paralysis and severe disability requiring intensive care in Neolithic Asia. Anthropological Science 117(2): 107-112. DOI: 10.1537/ase.081114

Pietrusewsky M, and Douglas MT. 1993. Tooth ablation in old Hawai'i. Journal of the Polynesian Society 102: 255-272.

Pietrusewsky M, Ikehara-Quebral R, and Douglas MT. 2006. The bioarchaeology of the Vat Komnou Cemetery, Angkor Borei, Cambodia. Bulletin of the Indo-Pacific Prehistory Association 26: 86-97.

Pottier C. 2006. Under the Western Baray Waters. In: Uncovering Southeast Asia's Past Selected papers from the 10th European Association of Southeast Asian Archaeologists, 2004, Bacus EA, Glover IG, and Pigott VC, (eds). National University of Singapore: Singapore. p 298-309.

Pottier C, Bolle A, Desbat A, Dupoizat M-F, Soutif D, Chevance JB, Vireak K, Kosal PC, Dara P, Vietstraete A and others. 2007. Mission Archéologique Franco-Khmére sur L'Aménagement du Territoire Angkorien. Siem Reap, Cambodia: Ecole Française D'Extrème-Orient. 
Reinecke A, Vin L, and Seng S. 2009. The First Golden Age of Cambodia: Excavation at Prohear. Embassy of the Federal Republic of Germany, Phnom Penh.: Bad Langensalza, Germany.

Sangvichien S. 1966. Neolithic skeletons from Ban Kao, Thailand, and the problem of Thai origins. Current Anthropology 7(2): 234-235.

Sangvichien S, Sirigaroon P, Jorgensen JB, and Jacob T. 1969. Archaeological Excavations in Thailand Volume III: Ban-Kao. Part 2: The Prehistoric Thai Skeletons. Munksgaard: Copenhagan.

Scott GR, and Turner CG. 1997. The Anthropology of Modern Human Teeth. Cambridge University Press: Cambridge.

Stark MT. 2004. Pre-Angkorian and Angkorian Cambodia. In: Southeast Asia: From Prehistory to History, Glover IG, and Bellwood P, (eds). Routledge Curzon: Abingdon, Oxfordshire. p 89-119.

Takenaka M, Mine K, Tsuchimochi K, and Shimada K. 2001. Tooth removal during ritual ablation in the Jomon period. Indo-Pacific Prehistory Association Bulletin 21: 49-52.

Tayanin GL, and Bratthall D. 2006. Black teeth: beauty or caries prevention? Practice and beliefs of the Kammu people. Community Dentistry and Oral Epidemiology 34(2): 81-86.

Tayles N. 1996. Tooth Ablation in Prehistoric Southeast Asia. International Journal of Osteoarchaeology 6: 333-345.

Tayles N, Domett K, and Hunt V. 1998. The People of Nong Nor. In: The Excavation of Nong Nor: A prehistoric site in central Thailand, Higham CFW, and Thosarat R, (eds). Department of Anthropology, University of Otago: Dunedin. p 321-368.

Tayles N, Halcrow S, and Domett K. 2007. The People of Noen U-Loke. In: The Origins of the Civilization of Angkor Volume II: The Excavation of Noen U-Loke and Non Muang Kao, Higham CFW, Kijngam A, and Talbot S, (eds). Thai Fine Arts Department: Bangkok. p 244-304.

Wales Q. 1937. Some ancient human skeletons excavated in Siam. Man XXXVII: 89-91.

Wales Q. 1964. 'Some ancient human skeletons excavated in Siam': A correction. Man 141143: 121.

Wallwork C. 2006. An osteological investigation ino unprovenienced remains from Koh Krabas, northwest Cambodia [Bachelor of Archaeological Practice with Combined Honours]. Canberra: Australian National University. 123 p.

Zumbroich TJ. 2009. 'Teeth as black as a bumble bee's wings': The ethnobotany of teeth blackening in Southeast Asia. Ethnobotany Research \& Applications 7: 381-398. 
Table 1: Ablation in the anterior teeth at Phum Snay and Phum Sophy

\begin{tabular}{|c|c|c|c|c|c|c|c|c|c|c|}
\hline & & Total & & \multicolumn{2}{|c|}{ Male } & \multicolumn{2}{|c|}{ Female } & \multicolumn{2}{|c|}{ ?sex } & Sex \\
\hline & & $\mathrm{n} / \mathrm{N}$ & $\%$ & $\mathrm{n} / \mathrm{N}$ & $\%$ & $\mathrm{n} / \mathrm{N}$ & $\%$ & $\mathrm{n} / \mathrm{N}$ & $\%$ & FET p-value \\
\hline \multirow[t]{2}{*}{ Phum Snay } & Maxillae & $74 / 123$ & 60.2 & $30 / 42$ & 71.4 & $32 / 52$ & 61.5 & $12 / 29$ & 41.4 & 0.3835 \\
\hline & Mandibles & $15 / 70$ & 21.4 & $3 / 4$ & 75.0 & $1 / 3$ & 33.3 & $11 / 63$ & 17.5 & 0.4857 \\
\hline \multirow[t]{2}{*}{ Phum Sophy } & Maxillae & $11 / 23$ & 47.8 & $6 / 12$ & 50.0 & $5 / 11$ & 45.5 & & & 1.000 \\
\hline & Mandibles & $3 / 39$ & 7.7 & $0 / 10$ & 0.0 & $2 / 15$ & 13.3 & $1 / 14$ & 7.1 & 0.5000 \\
\hline \multirow[t]{4}{*}{ Total } & Maxillae & $85 / 146$ & 58.2 & $36 / 54$ & 66.7 & $37 / 63$ & 58.7 & $12 / 29$ & 41.4 & 0.4454 \\
\hline & Mandibles & $18 / 109$ & 16.5 & $3 / 14$ & 21.4 & $3 / 18$ & 16.7 & $12 / 77$ & 15.6 & 1.000 \\
\hline & & \multicolumn{2}{|c|}{ Young adult } & \multicolumn{2}{|c|}{ Mid adult } & \multicolumn{2}{|c|}{ Old adult } & \multicolumn{2}{|c|}{ ?age adult } & Age \\
\hline & & $\mathrm{n} / \mathrm{N}$ & $\%$ & $\mathrm{n} / \mathrm{N}$ & $\%$ & $\mathrm{n} / \mathrm{N}$ & $\%$ & $\mathrm{n} / \mathrm{N}$ & $\%$ & $\mathrm{Chi}^{2} \mathrm{p}$-value \\
\hline \multirow[t]{2}{*}{ Phum Snay } & Maxillae & $13 / 29$ & 44.8 & $13 / 19$ & 68.4 & $7 / 9$ & 77.8 & $41 / 65$ & 63.1 & 0.1086 \\
\hline & Mandibles & $3 / 15$ & 20.0 & $4 / 21$ & 19.0 & $2 / 6$ & 33.3 & $6 / 27$ & 22.2 & 0.9433 \\
\hline \multirow[t]{2}{*}{ Phum Sophy } & Maxillae & $5 / 10$ & 50.0 & $1 / 4$ & 25.0 & $3 / 6$ & 50.0 & $2 / 4$ & 50.0 & 0.3932 \\
\hline & Mandibles & $0 / 11$ & 0.0 & $0 / 10$ & 0.0 & $2 / 10$ & 20.0 & $1 / 7$ & 14.3 & $\mathrm{n} / \mathrm{a}$ \\
\hline \multirow[t]{2}{*}{ Total } & Maxillae & $18 / 39$ & 46.2 & $14 / 23$ & 60.9 & $10 / 15$ & 66.7 & $43 / 69$ & 62.3 & 0.2627 \\
\hline & Mandibles & $3 / 26$ & 13.0 & $4 / 31$ & 12.9 & $4 / 16$ & 25.0 & $7 / 34$ & 20.1 & 0.8757 \\
\hline
\end{tabular}

$\mathrm{n}=$ number affected; $\mathrm{N}=$ number observable 


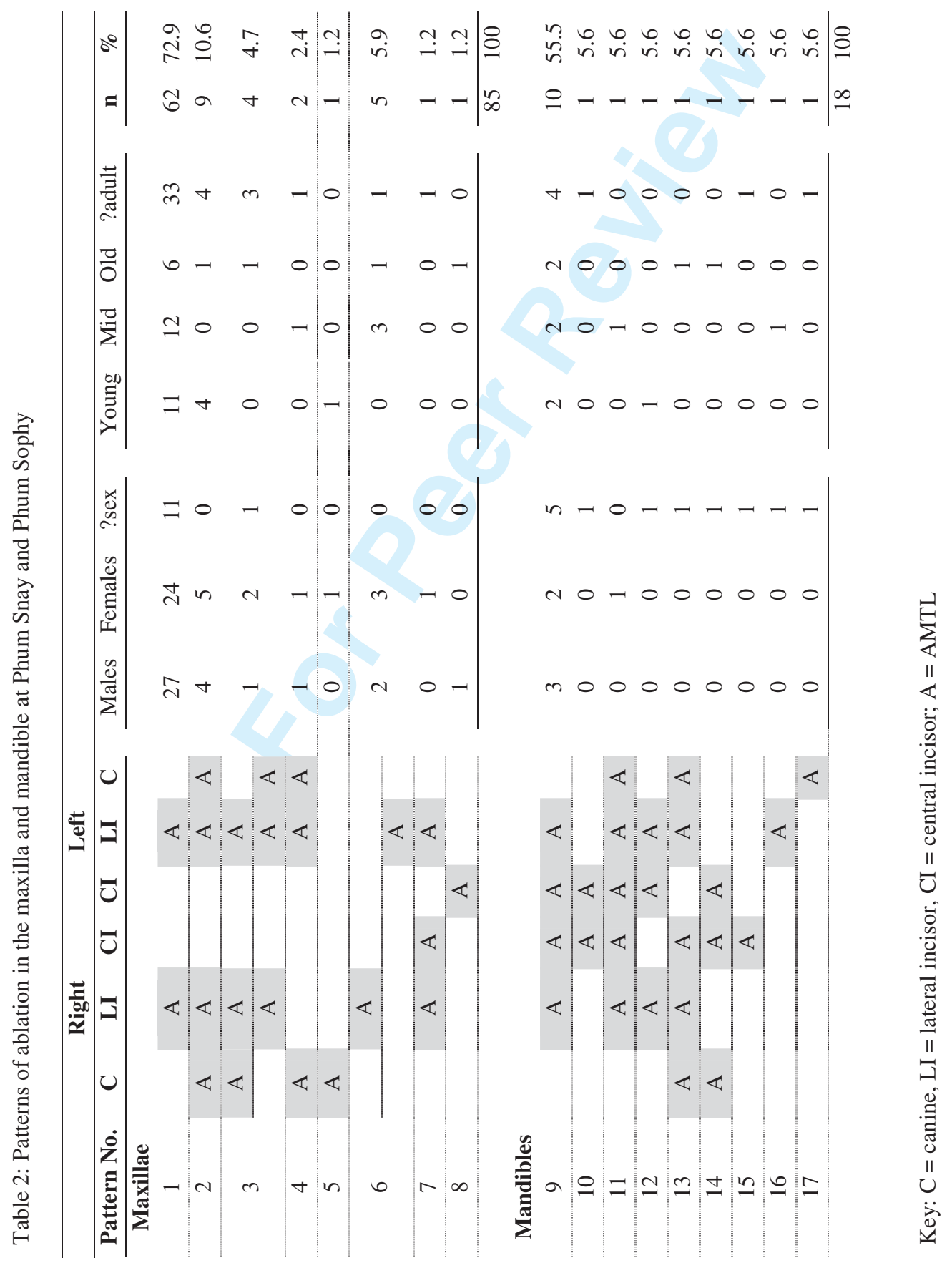


Table 3: Patterns of intentional filing in the maxillae of Phum Snay and Phum Sophy.

\begin{tabular}{|c|c|c|c|c|}
\hline \multicolumn{2}{|r|}{ Maxilla } & \multirow[t]{2}{*}{ Crown Abrasion } & \multicolumn{2}{|c|}{ Individuals affected } \\
\hline & & & Phum Snay & Phum Sophy \\
\hline A & & $\begin{array}{l}\text { Central incisors: distal } \\
\text { Lateral incisors: mesial. } \\
\text { Canines unaffected }\end{array}$ & $\begin{array}{l}2 \text { Young } \\
\text { adults } \\
1 \text { Older adult }\end{array}$ & \\
\hline B & & $\begin{array}{l}\text { Central incisors: distal. } \\
\text { Lateral incisors: mesial and } \\
\text { distal; pointed. } \\
\text { Canines unaffected. }\end{array}$ & $\begin{array}{l}2 \text { young adult } \\
\text { female } \\
2 \text { adults }\end{array}$ & \\
\hline $\mathrm{C}$ & & $\begin{array}{l}\text { Central incisors: distal. } \\
\text { Lateral incisors: mesial and } \\
\text { distal; pointed. } \\
\text { Canines: mesial and distal; } \\
\text { pointed. }\end{array}$ & 1 adult male & $\begin{array}{l}1 \text { Young adult } \\
\text { female } \\
1 \text { Young adult } \\
\text { male } \\
1 \text { Older adult } \\
\text { male* }\end{array}$ \\
\hline $\mathrm{D}$ & & $\begin{array}{l}\text { Central incisors: distal. } \\
\text { Lateral incisors: AMTL. } \\
\text { Canines unaffected }\end{array}$ & $\begin{array}{l}1 \text { Middle aged } \\
\text { adult male }\end{array}$ & \\
\hline
\end{tabular}

\footnotetext{
* these individuals are thought to belong to this pattern, but not all had complete anterior maxillae.
} 
Table 4: Patterns of intentional filing in the mandibles of Phum Snay and Phum Sophy.

\begin{tabular}{|c|c|c|c|c|}
\hline \multirow{2}{*}{\multicolumn{2}{|c|}{ Mandible }} & \multirow[t]{2}{*}{ Crown Abrasion } & \multicolumn{2}{|c|}{ Individuals affected } \\
\hline & & & Phum Snay & Phum Sophy \\
\hline $\mathrm{E}$ & & $\begin{array}{l}\text { Central incisors: distal. } \\
\text { Lateral incisors: mesial and } \\
\text { distal; pointed. } \\
\text { Canines unaffected. }\end{array}$ & $\begin{array}{l}1 \text { middle aged } \\
\text { adult } \\
1 \text { young adult }\end{array}$ & \\
\hline $\mathrm{F}$ & & $\begin{array}{l}\text { Central incisors: distal. } \\
\text { Lateral incisors: mesial and } \\
\text { distal; pointed. } \\
\text { Canines: mesial and distal; } \\
\text { pointed. }\end{array}$ & & $\begin{array}{l}1 \text { adult female } \\
\& 1 \text { middle } \\
\text { aged adult: } \\
\text { Pattern F, H or } \\
\text { J. }\end{array}$ \\
\hline $\mathrm{G}$ & & $\begin{array}{l}\text { Central incisors: distal and } \\
\text { mesial, pointed } \\
\text { Lateral incisors: mesial and } \\
\text { distal; pointed. } \\
\text { Canines unaffected. }\end{array}$ & $\begin{array}{l}1 \text { older adult } \\
1 \text { young adult } \\
1 \text { middle aged } \\
\text { adult } \\
1 \text { adult }\end{array}$ & \\
\hline $\mathrm{H}$ & & $\begin{array}{l}\text { Central incisors: distal and } \\
\text { mesial, pointed } \\
\text { Lateral incisors: mesial and } \\
\text { distal; pointed. } \\
\text { Canines: mesial and distal; } \\
\text { pointed. }\end{array}$ & 1 adult & \\
\hline $\mathrm{I}$ & & $\begin{array}{l}\text { Central incisors: distal; } \\
\text { and worn much lower than } \\
\text { lateral incisors. } \\
\text { Lateral incisors: mesial. } \\
\text { Canines unaffected. }\end{array}$ & 1 young adult & \\
\hline $\mathrm{J}$ & & $\begin{array}{l}\text { Central incisors: distal; } \\
\text { and worn much lower than } \\
\text { lateral incisors. } \\
\text { Lateral incisors: mesial. } \\
\text { Canines: mesial and distal; } \\
\text { pointed. }\end{array}$ & & $\begin{array}{l}1 \text { middle aged } \\
\text { adult } \\
1 \text { middle aged } \\
\text { adult female }\end{array}$ \\
\hline
\end{tabular}




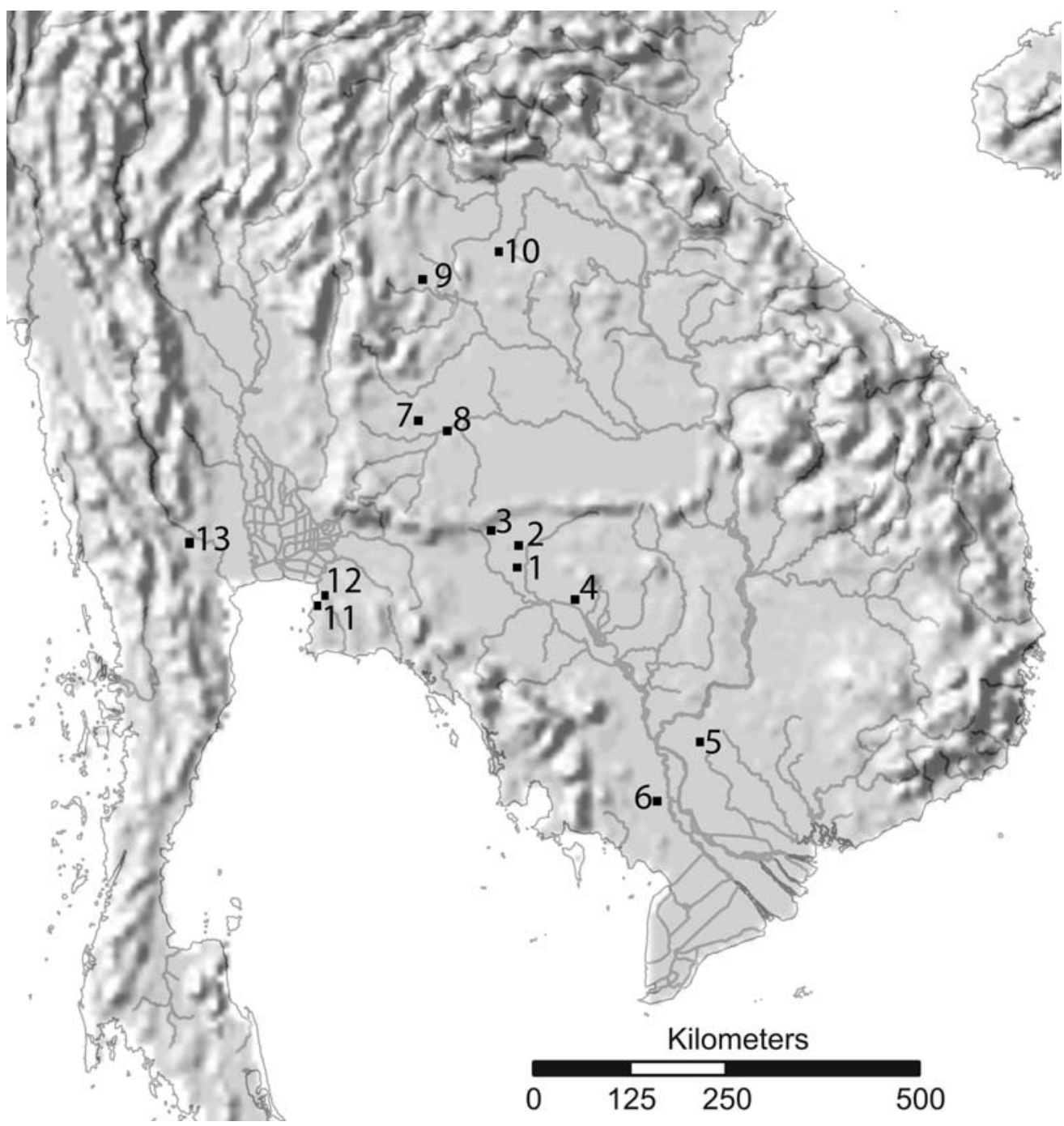

Figure 1: Location of prehistoric sites mentioned in the text. 1.Phum Snay, Krasang Thmei, 2. Phum Sophy, 3. Koh Krabas, 4.Prei Khmeng, Koh Ta Meas and Angkor (Siem Reap), 5.Prohear, 6.Angkor Borei, 7.Noen U-Loke, Ban Non Wat and Ban Lum Khao, 8.Phimai, 9.Non Nok Tha, 10. Ban Chiang, 11. Khok Phanom Di, 12. Nong Nor, 13. Ban Kao. $122 \times 128 \mathrm{~mm}(600 \times 600 \mathrm{DPI})$ 


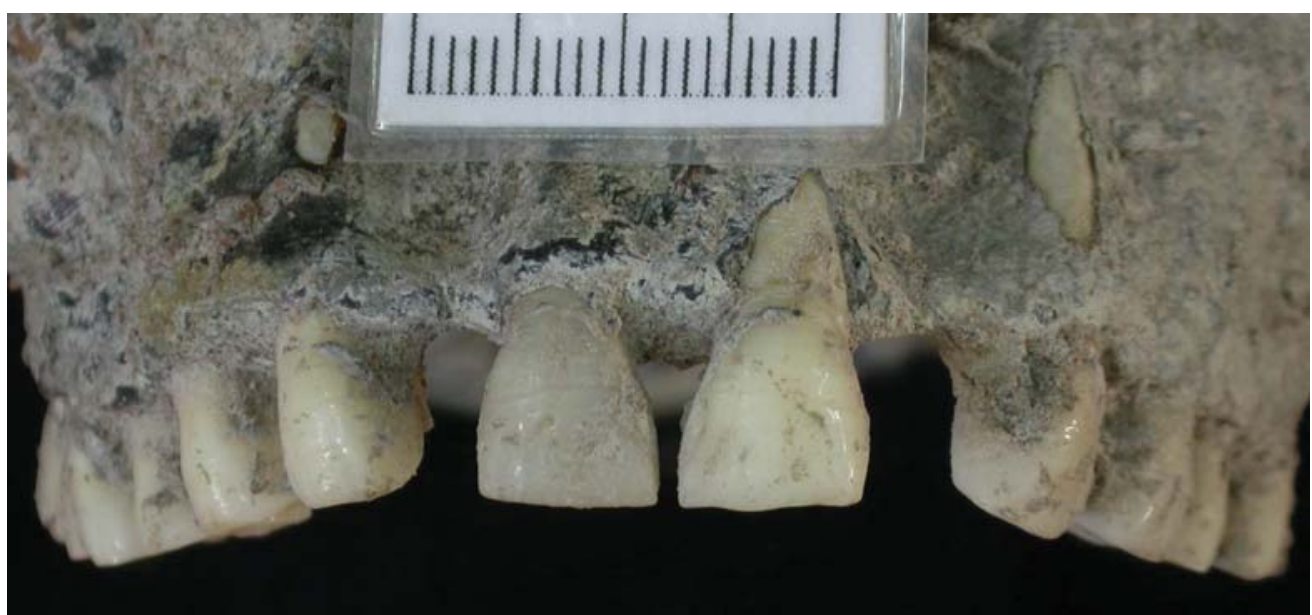

Figure 2: Maxilla (adult, female) showing Pattern 1 (Table 2): ablated upper lateral incisors. There is also possibly some slight distal migration of the central incisors. (Snay PS L9). $160 \times 74 \mathrm{~mm}(300 \times 300 \mathrm{DPI})$ 


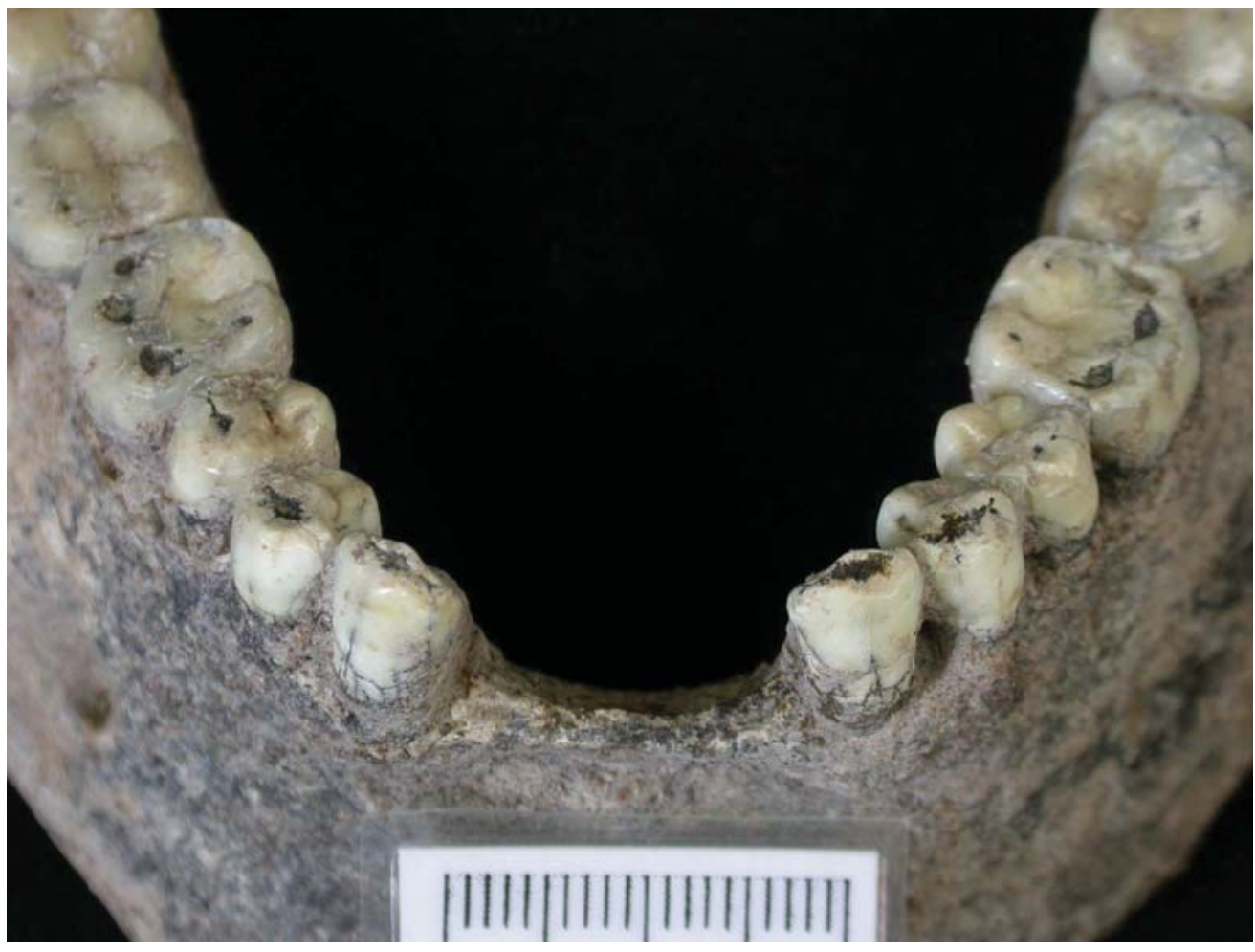

Figure 3: Mandible (middle aged adult, male) showing Pattern 9 (Table 2), the most common ablation pattern with the removal of all four incisors. (Snay PS03 B6) $192 \times 144 \mathrm{~mm}(300 \times 300 \mathrm{DPI})$ 
Figure 4: One of the few individuals with an occluding maxilla and mandible. This middle aged male from Phum Snay shows ablation of the upper lateral incisors (Pattern 1) and all four lower incisors (Pattern 9). Note: the deviation of the upper central incisors is the result of postmortem damage. (PS03 B6). $120 \times 81 \mathrm{~mm}(300 \times 300$ DPI $)$ 


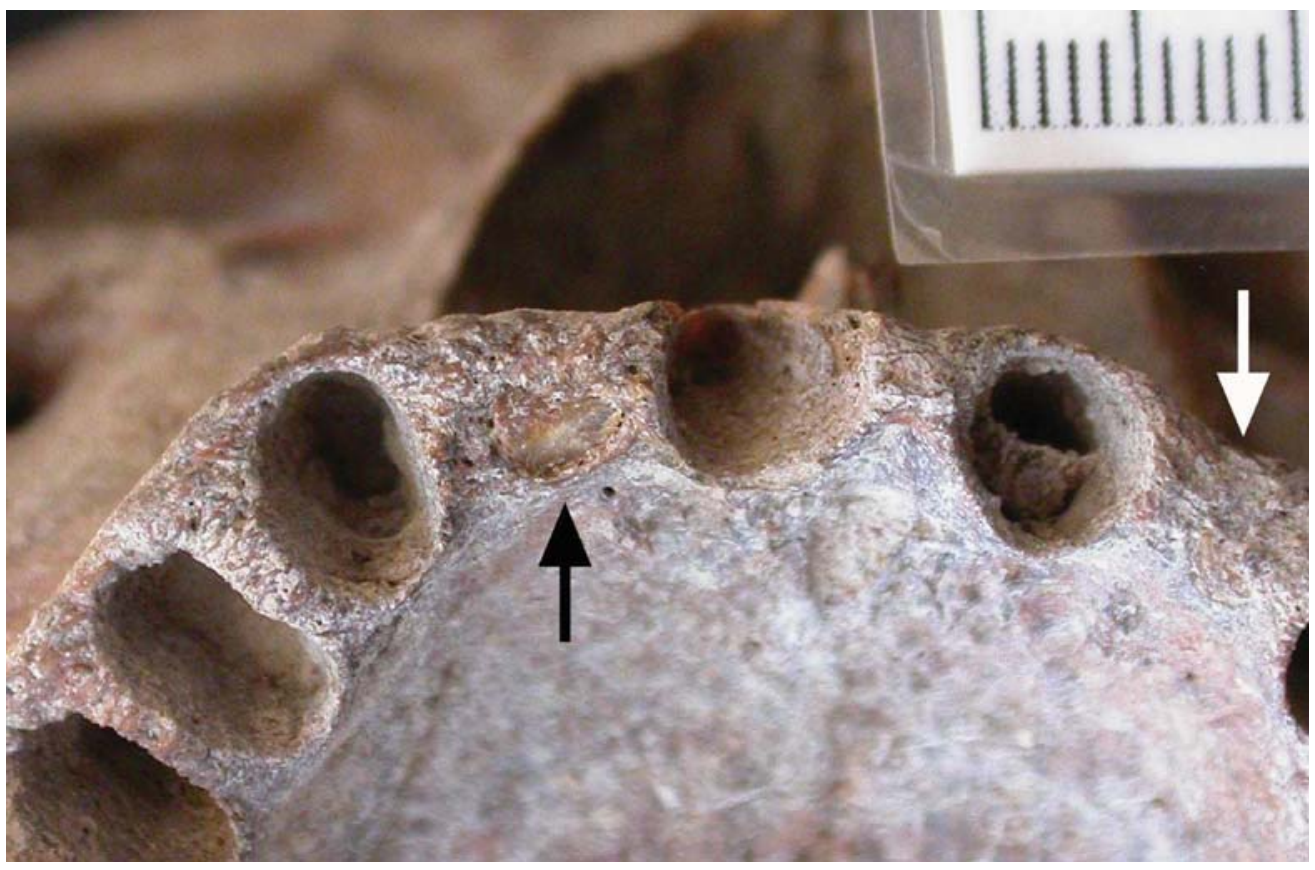

Figure 5: Anterior maxilla (adult, female) showing a remnant of the root of the right lateral incisor visible through the remodelling of the socket (black arrow). The socket of the left lateral incisor has fully remodelled (white arrow) (Snay WBC5). $121 \times 79 \mathrm{~mm}(300 \times 300 \mathrm{DPI})$ 
Figure 6: This maxilla, a young adult of indeterminate sex, shows Pattern A (Table 3 ) of abrasion between the central and lateral incisors creating an inverse $\mathrm{V}$-shaped hole between the teeth. No mandible was associated with this specimen. (Snay PS L1). $136 \times 90 \mathrm{~mm}(300 \times 300 \mathrm{DPI})$ 


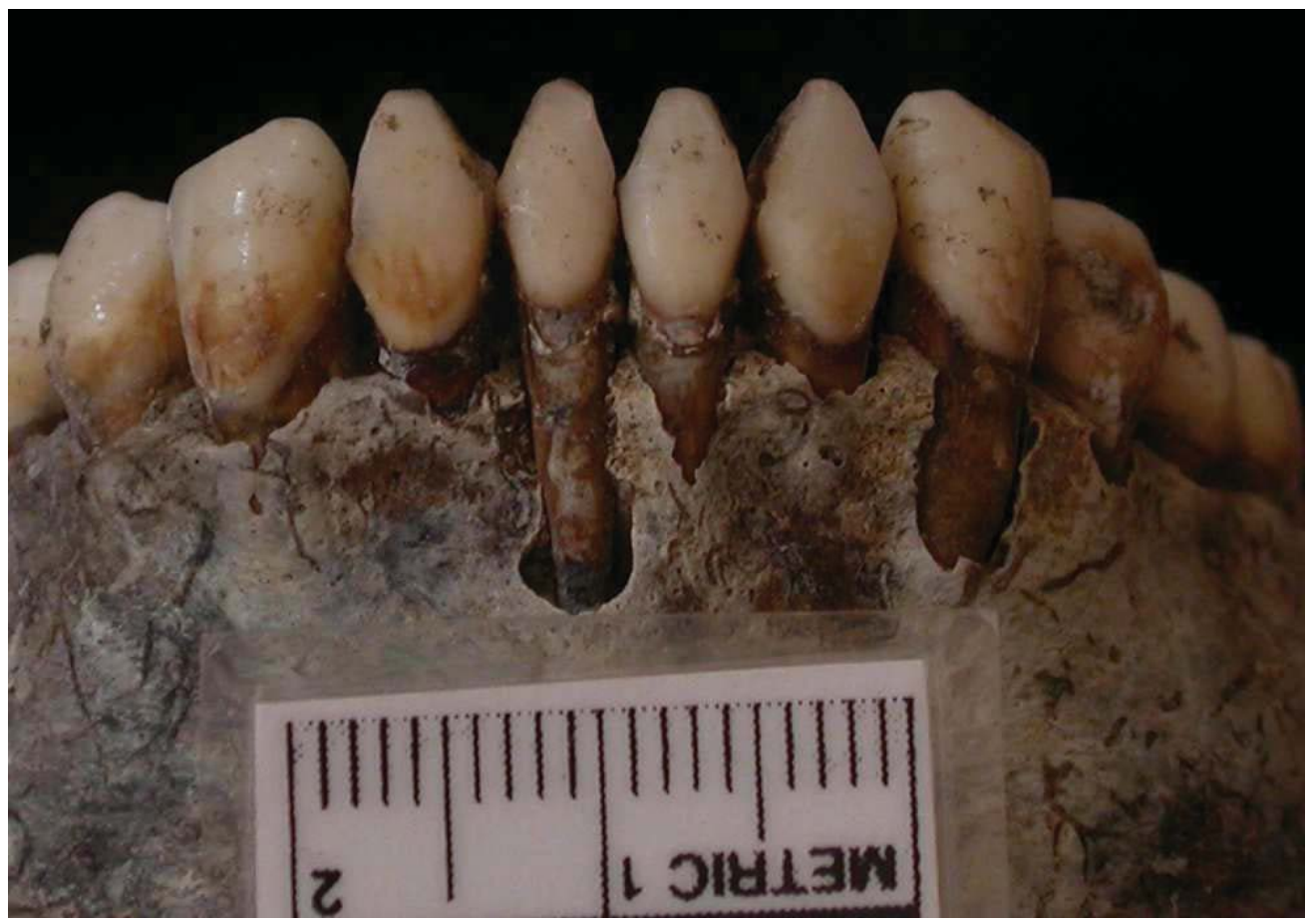

Figure 7: An example of the most common pattern of abrasion, Pattern $\mathrm{G}$ (Table 4), in the mandible, where all four incisors are filed to a point (Snay WLM 59) (young adult of unknown sex). $83 \times 58 \mathrm{~mm}(300 \times 300 \mathrm{DPI})$ 
Figure 8: Abrasion Pattern I (Table 4) in the mandible involving the incisors filed to create V-shaped holes but with the central incisors also considerably lower than the lateral incisors. (Snay WBM3) (Young adult of unknown sex). $150 \times 112 \mathrm{~mm}(300 \times 300 \mathrm{DPI})$ 